\title{
Experimental infection by Anaplasma marginale in buffaloes and cattle: clinical, hematological, molecular and pathological aspects ${ }^{1}$
}

\author{
Danillo H.S. Lima ${ }^{2 *}$ (D), Wagner M.S. Vinhote ${ }^{2}$, Daniel G. Ubiali ${ }^{6}$ (D), \\ Pierre C. Soares ${ }^{7}$, Matheus D. Cordeiro ${ }^{5}$, Jenevaldo B. Silva ${ }^{3}$, Adivaldo H. Fonseca ${ }^{5}$ \\ and José D. Barbosa ${ }^{4}$ (D)
}

\begin{abstract}
Lima D.H.S., Vinhote W.M.S., Ubiali D.G., Soares P.C., Cordeiro M.D., Silva J.B., Fonseca A.H. \& Barbosa J.D. 2019. Experimental infection by Anaplasma marginale in buffaloes and cattle: clinical, hematological, molecular and pathological aspects. Pesquisa Veterinária Brasileira 39(9):700-709. Faculdade de Medicina Veterinária, Instituto de Medicina Veterinária, Campus de Castanhal, Universidade Federal do Pará, Rodovia BR-316 Km 61, Castanhal, PA 68741-740, Brazil. E-mail: danillo.lima@ifpa.edu.br

The study aimed to evaluate and compare the clinical, laboratory and pathological aspects of buffalo and bovine experimentally infected with AmRio 2 strain of Anaplasma marginale. Four Murrah buffaloes and four crossbred cattle were used in the experiment, which two animals of each species were splenectomized. Strain AmRio 2 of $A$. marginale was inoculated in all experimental animals. Clinical exams, Packed Cell Volume (PCV), blood counts, blood smears, rickettsemia, necropsy and histopathology were performed in all cases. Semi-Nested-PCR (snPCR) for the $m s p 5$ and snPCR for the $m s p 1 \alpha$ target gene for identification of $A$. marginale in blood samples from animals was done. From positive samples for $m s p 1 \alpha$ snPCR, samples were analyzed for the amino acid sequences of this gene. Two splenectomized cattle presented apathy, pale mucous membranes, jaundice, hyperthermia, and severe anemia. The remaining experimental animals did not show clinical signs. The rickettsemia in all animals was less than $1 \%$. The mean PCV of the splenectomized cattle was below $20 \%$ at two-time points after infection. On the blood count, the main changes were observed in splenectomized calves and were characterized by a decrease in red blood cells, hemoglobin, PCV and platelets $(\mathrm{p}<0.05)$. All animals presented leukocyte elevation by increased lymphocytes, however, with no significant difference. The average prepatent period was two days in all the animals. The average incubation period in cattle that became ill was 25.5 days, and death occurred, on average, 63 days after inoculation of the strain. The necropsy findings were characterized by pale carcass, ascites, enlarged liver, distended gallbladder, and thick bile. Histopathological findings included infiltration of macrophages and lymphocytes in various organs, hepatic sinusoidal dilatation, and necrosis of the large intestine. In snPCR for the $m s p 5$ gene, $100 \%$ of the animals were positive in at least one evaluation. And in the snPCR for the infection of the $m s p 1 \alpha$ target gene was also found in all animals in at least one sample evaluated.
\end{abstract}

\footnotetext{
${ }^{1}$ Received on April 2, 2019.

Accepted for publication on May 4, 2019.

${ }^{2}$ Instituto Federal do Pará (IFPA), Campus Rural de Marabá (CRMB), Rodovia BR-155 Km 25, Marabá, PA 68508-970, Brazil. E-mail: marcelo.vinhote@ifpa.edu.br; *Corresponding author: danillo.lima@ifpa.edu.br

${ }^{3}$ Instituto de Ciências Agrárias (ICA), Universidade Federal dos Vales do Jequitinhonha e Mucuri (UFVJM), Av. João Narciso 1380, Bairro Cachoeira, Unaí, MG 38610-000, Brazil. E-mail: jenevaldo@hotmail.com

${ }^{4}$ Faculdade de Medicina Veterinária, Instituto de Medicina Veterinária, Campus de Castanhal, Universidade Federal do Pará (UFPA), Rodovia BR316 Km 61, Castanhal, PA 68741-740, Brazil. E-mails: diomedes@ufpa.br
}

\footnotetext{
${ }^{5}$ Laboratório de Doenças Parasitárias, Departamento de Epidemiologia e Saúde Pública, Universidade Federal Rural do Rio de Janeiro (UFRRJ), Rodovia BR-465 Km 7, Seropédica, RJ 23890-000, Brazil. E-mails: adivaldofonseca@yahoo.com, mathcordeiro@hotmail.com

${ }^{6}$ Departamento de Epidemiologia e Saúde Pública, Instituto de Veterinária (IV), Universidade Federal do Rio de Janeiro (UFFRJ), Seropédica, RJ 23890000, Brazil. E-mail: danielubiali@hotmail.com

${ }^{7}$ Departamento de Medicina Veterinária, Universidade Federal Rural de Pernambuco (UFRPE), Rua Dom Manuel de Medeiros s/n, Bairro Dois Irmãos, Recife, PE 52171-900, Brazil. E-mail: pcastro.pe@gmail.com
} 
However, sequencing revealed only five animals, including the bovine which died, with a similarity of the amino acid sequences with AmRio 2 strain of $A$. marginale. It is concluded that the splenectomized cattle died due to anaplasmosis caused by the inoculated strain and the buffalo were more resistant compared to cattle. Buffaloes can be an alternative to cattle rearing in areas with a high occurrence of clinical cases of anaplasmosis.

INDEX TERMS: Experimental infection, Anaplasma marginale, buffaloes, cattle, clinics, hematology, molecular aspect, pathology, anaplasmosis, calves, AmRio 2 strain, clinical signs, PCR, bacterioses.

\begin{abstract}
RESUMO.- [Infecção experimental de Anaplasma marginale em búfalos e bovinos: aspectos clínicos, hematológicos, moleculares e patológicos.] 0 estudo teve como objetivo avaliar e comparar os aspectos clínicos, laboratoriais e patológicos de búfalos e bovinos infectados experimentalmente com estirpe AmRio 2 de Anaplasma marginale. Para isso, foram utilizados quatro bubalinos Murrah e quatro bovinos mestiços, sendo dois animais de cada espécie, esplenectomizados. Estirpe AmRio 2 de A. marginale foi inoculada em todos os animais. Foram realizados exames clínicos, hematócrito, hemograma, esfregaço sanguíneo com avaliação de riquetsemia, necropsia e histopatologia, além de, Semi-Nested-PCR (snPCR) para o gene alvo $m s p 5$ e snPCR para o gene alvo $m s p 1 \alpha$ para identificação de A. marginale nas amostras de sangue dos ruminantes. A partir das amostras positivas na snPCR $m s p 1 \alpha$, foram selecionadas amostras para análise das sequências de aminoácidos deste gene. Dois bovinos esplenectomizados apresentaram apatia, mucosas pálidas, icterícia, hipertermia e anemia severa. O restante dos animais não apresentou sintomatologia clínica. A riquetsemia em todos os animais foi menor que $1 \%$. A média do hematócrito dos bovinos esplenectomizados esteve abaixo de $20 \%$ em dois momentos após infecção. Ao hemograma, as principais alterações observadas foram nos bovinos esplenectomizados e caracterizaram-se por redução de hemácias, hemoglobina, hematócrito e plaquetas $(p<0,05)$. Todos os animais apresentaram elevação de leucócitos por aumento de linfócitos, porém, sem diferença significativa. 0 período pré-patente médio foi de dois dias em todos os animais. 0 período de incubação médio nos bovinos que adoeceram foi de 25,5 dias e estes morreram em média 63 dias após inoculação da estirpe. Os achados de necropsia caracterizaram-se por carcaça pálida, ascite, aumento de volume do fígado, vesícula biliar distendida e bile espessa. À histopatologia, verificou-se infiltração de macrófagos e linfócitos em diversos órgãos, dilatação dos sinusoides hepáticos e necrose do intestino grosso. A snPCR para o gene $m s p 5$, revelou $100 \%$ dos animais positivos em pelo menos um momento de avaliação. E na snPCR para o gene alvo $m s p 1 \alpha$ também verificou-se infecção em todos os animais em pelo menos uma amostra avaliada. Entretanto, o sequenciamento revelou apenas cinco animais, incluindo os bovinos que morreram, com similaridade das sequências de aminoácidos com estirpe AmRio 2 de A. marginale. Conclui-se que os bovinos esplenectomizados morreram em virtude de anaplasmose provocada pela estirpe inoculada e os bubalinos foram mais resistentes em comparação aos bovinos. Finalmente, os búfalos podem ser uma alternativa à criação de bovinos em áreas com alta ocorrência de casos clínicos de anaplasmose.
\end{abstract}

TERMOS DE INDEXAÇÃO: Infecção experimental, Anaplasma marginale, búfalos, bovinos, clínica, hematologia, aspecto molecular, patologia, anaplasmose, bezerros, estirpe AmRio 2, sinais clínicos, PCR, bacterioses.

\section{INTRODUCTION}

Anaplasma marginale is an obligate intracellular bacterium. It can be biologically transmitted by ticks, and mechanically transmitted by hematophagous dipterans, infected blood in photites, and also transplacental (Aubry \& Geale 2011, Grau et al. 2013). This rickettsia causes a condition called anaplasmosis, which is endemic in tropical and subtropical areas, and result in considerable economic loses for the beef and dairy industries worldwide (Kocan et al. 2015).

Anaplasmal cattle may present fever, weight loss, abortion, lethargy, jaundice, and often death mainly of animals over two years of age (Kocan et al. 2003). Buffaloes present with lack of appetite, depression, ruminal atony, jaundice, pale mucous membranes (Srivastava \& Ahluwalia 1974, Reddy et al. 1988), weakness, anorexia, tachycardia and difficulty in breathing (Vatsya et al. 2013).

Despite the confirmed presence of this rickettsia in buffalo herds (Silva et al. 2014a, 2014b, 2014c, 2015), there is little knowledge about the development of anaplasmosis in this species. Furthermore, there is no research that simultaneously evaluates the pathogenicity of $A$. marginale in cattle and buffaloes and compares the effects of the disease between the two species. This fact is relevant because buffaloes play an important role as reservoirs for A. marginale, serving as a source of infection for cattle when raised in the same location (Sharma 1987, Silva et al. 2014c). This situation is frequently observed in some regions of the state of Pará, especially in Marajó Island, which has the largest herd of buffaloes in Brazil (IBGE 2016).

Based on this, the present study aimed to evaluate and compare the clinical, laboratory and pathological aspects of buffaloes and experimentally infected cattle with AmRio 2 strain of $A$. marginale (Genbank: KM023771).

\section{MATERIALS AND METHODS}

Study location. The experiment was developed at the "Instituto Federal do Pará, Campus Rural de Marabá", (IFPA-CRMB) (5³3’44.5”S and $49^{\circ} 06^{\prime} 01.1^{\prime \prime}$ ), Marabá, Pará, Brazil. The study period took place from January to May 2017, when the daily averages of environmental conditions consisted of $26.1^{\circ} \mathrm{C}$ temperature, $91.3 \%$ relative humidity and $8.7 \mathrm{~mm}$ rainfall. Data collected by the hydrometeorological station located at IFPA-CRMB.

Animals and handling. This study was approved by the Animal Use Ethics Committee under protocol number 2134171215 registered in December 2015.

We used four buffalos (Bubalus bubalis) of the breed Murrah and four crossbred cattle (Bos taurus $\times$ Bos indicus) with average age of 10 months, male, not castrated, and average weight of $148 \mathrm{~kg}$. Two animals of each species were splenectomized. 
The animals were raised in two different environments at different times of the experiment. At first, they were separated by species and kept in two screened stalls, with a maximum number of four animals per stall. The food was based on Brachiaria brizantha cv. Marandu, 21\% crude protein food ( $0.5 \mathrm{~kg} /$ animal $/$ day), mineral salt ( $40 \mathrm{~g} / \mathrm{animal} /$ day) and water as needed. Then, the animals were raised on $B$. brizantha cv. Marandu.

Since the animals came from anaplasmose endemic regions, we performed semi-nested PCR (SnPCR) before the experiment and verified that the animals were positive for Anaplasma marginale. Therefore, 160 days before the beginning of the experiment, the animals were treated with imidocarb dipropionate, $5 \mathrm{mg} / \mathrm{kg}$ subcutaneously, single application and long-acting oxytetracycline, $20 \mathrm{mg} / \mathrm{kg}$ intramuscularly, three times, 48 hours apart. Fifteen days after treatment, we performed an SnPCR and verified that two bovines not splenectomized were still infected by a native strain of A. marginale. Thus, 65 days before rickettsia inoculation, we applied a second treatment on all animals using the above-mentioned drugs and doses. However, only non-splenectomized cattle remained positive in two snPCRs performed at weekly intervals between blood samples. These animals came from the same state, where there was a history of clinical cases of anaplasmosis in calves. Nevertheless, we decided to maintain these two cattle in the experiment due to the difficulty in obtaining negative animals for $A$. marginale in the region.

All animals were bathed with $12.5 \%$ amitraz at a dilution of $20 \mathrm{ml}$ in $10 \mathrm{l}$ of water and $2.5 \mathrm{l}$ dose of mixture/animal; we sprayed $15 \%$ cypermethrin into the environment at the dilution of $20 \mathrm{ml}$ in $20 \mathrm{l}$ of water and $10 \mathrm{l}$ dose of the mixture/well twice, with 21 days apart in both treatments.

Experimental design. Four buffaloes (two non-splenectomized and two splenectomized) and four cattle (two non-splenectomized and two splenectomized) were inoculated with AmRio 2 strain of A. marginale (Baêta et al. 2015). We performed periodical clinical examinations, hematocrit blood samples, blood count and blood smear with rickettsemia evaluation to verify the infection and the possible development of anaplasmosis in the studied animals. We performed necropsy in the dead animals, collected samples and performed histopathological exam. We also performed molecular analysis for the identification of $A$. marginale using Semi-Nested PCR (snPCR) with the animals' blood samples.

The experiment was divided in two phases. In the first, the ruminants remained for 30 days in screened pens. The aim was to evaluate and describe the clinical changes more carefully. In the second, the ruminants were remained for 58 days in paddocks. This phase aimed to evaluate, in a larger chronological space, the occurrence of anaplasmosis in experimental animals and a possible occurrence of genetic diversity of the AmRio 2 strain of $A$. marginale.

Inoculation of AmRio 2 strain of Anaplasma marginale. The inoculum used for application to animals was the AmRio 2 strain of $A$. marginale, kept in culture of embryonic Ixodes escapularis tick cells (strain IDE8) (Baêta et al. 2015). The inoculum was prepared from a culture with a percentage of infection higher than $70 \%$, evaluated by cytocentrifuge smears under optical microscope (Olimpus ${ }^{\circledR}$ ). Upon observation of the smear and confirmation of the minimum infection value, the inoculum vials were rinsed inside the laminar flow using a sterile Pasteur pipette $\left(\mathrm{Kasvi}^{\circledR}\right)$. Subsequently, the cell media was transferred to a curved needle syringe and then discarded in sterile beaker. The medium contained in the beaker was transferred in the volume of one (1) mL to three (3) mL syringe with $40 \times 12 \mathrm{~mm}$ needle for inoculation in animals, which was performed through the jugular vein.
Clinical examination. Clinical examination was performed according to Dirksen et al. (1993) to verify rectal temperature (RT), heart rate (HR), respiratory rate (RR), ruminal movements (MR), mucosal staining, lymph node size and behavior. Physiological parameters were obtained by daily clinical examinations 20 days before starting the study. And the means obtained in these tests were parameters for comparison with the data obtained after the rickettsia inoculation.

After inoculation, clinical examinations were performed from D0 (day of inoculation) to D30 in the morning, once a day, during the animals' stay in the pens. Temperature was measured with a digital thermometer twice a day, with an average interval of 12 hours between measurements. From the moment the animals started being raised on paddocks, they were observed daily for behavior, food and water intake and clinical examinations, as well as temperature measurements, performed once a week. We used previously described values as standard values for cattle (Dirksen et al. 1993) and buffaloes (Moraes Júnior et al. 2010).

Hematological and parasitological evaluation. We collected blood samples for blood count, manual hematocrit and blood smear once a week for 30 days before the start of the experiment. The averages obtained in this period constituted the values before inoculation, which were considered as control. From the inoculation, for blood count, blood samples were collected in D7, D14, D21, D28 and D48 through the jugular vein, with the aid of a vacutainer system. The samples were packed in tubes with EDTA (Ethylenedeamine Tetra Acetic Acid), which were taken to a commercial laboratory located in Marabá, Pará, where they were routinely processed in BC-2800Vet ${ }^{\circledR}$ device (Shenzhen Mindray Bio-Medical Eletronics ${ }^{\circledR}$, Germany) and the reference standards adopted were those described by Jain (1993) for cattle and Abd Ellah et al. (2014) for buffaloes. For the purpose of analysis of hematocrit results, only the results of the manual technique were used, disregarding the values obtained in the automated technique.

Manual hematocrit and rickettsemia evaluation were performed in D2, D5, D7, D9, D12, D14, D16, D19, D21, D26, D28 (period in the stalls), D35, D42, D48, D56, D60 and D70 (period in the pasture). The hematocrit was performed according to the specifications of Thrall et al. (2007). Blood smears were performed using a commercial kit (Instant-Prov ${ }^{\circledR}$ ) for fixing and staining. The prepared slides were analyzed under a light microscope with a $100 \times$ objective and $10 \times$ eyepiece, in immersion oil. Rickettsemia was obtained by visualizing 40 microscopic fields to calculate the percentage of infected red blood cells. Animals were considered positive when presenting $\geq 0.01 \%$ of infected red blood cells.

In parallel to blood sampling for hematocrit, blood smear and rickettsemia, snPCR scans were performed by analysis of the genes msp5 and msp1a of the AmRio 2 strain of A. marginale.

Necropsy and histopathology. During necropsies of two animals we collected several organs, which were stored in $10 \%$ buffered formaldehyde and sent to the "Setor de Anatomia Patológica" (SAP) of the "Universidade Federal Rural do Rio de Janeiro" (UFRRJ), where they were submitted to histopathological routine tests, cut into $5 \mu \mathrm{m}$ and stained with hematoxylin and eosin (HE).

DNA extraction. DNA samples were extracted from $200 \mu \mathrm{l}$ of animal blood using the protocol described by Sambrook \& Russel (2001). We added to the samples $20 \mu$ Proteinase $K(20 \mathrm{mg} / \mathrm{mL})$ and $200 \mu \mathrm{l}$ digestion buffer (20mM Tris- $\mathrm{HCl}, 20 \mathrm{mM}$ EDTA, $400 \mathrm{mM} \mathrm{NaCl}$, $1 \%$ Sodium Dodecyl Sulphate and $10 \mathrm{mM} \mathrm{CaCl} 2$ ). After homogenizing the sample by inversion, it was incubated at $56^{\circ} \mathrm{C}$ overnight. DNA extraction was started with the addition of $460 \mu \mathrm{l}$ chloroform, 
vigorous homogenization and subsequent addition of $240 \mu \mathrm{l}$ of protein precipitation solution (3M potassium acetate, $11 \%$ glacial acetic acid). After homogenization, the mixture was centrifuged at maximum speed for $10 \mathrm{~min}$. At the end of centrifugation, the aqueous portion was transferred to a microcentrifuge tube containing $700 \mu \mathrm{l}$ of cold isopropanol for DNA precipitation. The total DNA precipitate was centrifuged at maximum speed for $4 \mathrm{~min}$. The supernatant was discarded, and the formed pellets were washed twice with $1 \mathrm{~mL}$ cold absolute ethanol and $70 \%$ alcohol at full speed for $2 \mathrm{~min}$. The pellets were oven dried at $56^{\circ} \mathrm{C}$ for $15 \mathrm{~min}$. Then the DNA was rehydrated with $100 \mu \mathrm{l} \mathrm{TE} 1 \mathrm{X}$ at $56^{\circ} \mathrm{C}$ for 1 hour and stored in a freezer until testing was performed.

snPCR for target genes msp5 e msp1 $\alpha$. For screening of positive and negative animals, snPCR was performed with the Amar primers msp5 eF (5'GCATAGCCTCCGCGTCTTTC 3'), Amar msp5 iF (5'TACACGTGCCCTACCGAGTTA 3') and Amar msp5 eR (5'TCC TCG CCTTGGCCCTCAGA 3'), previously described by Torioni de Echaide et al. (1998) and optimized by Singh et al. (2012). The first reaction was performed with the primers eF and eR, and the second reaction used the primers iF and eR. The reactions were performed in a thermal cycler (Bio Rad $\mathrm{T} 100^{\mathrm{TM}}$ ) with the following conditions: Polymerase activation at $95^{\circ} \mathrm{C}$ for $5 \mathrm{~min}$, initial denaturation at $94^{\circ} \mathrm{C}$ for $1 \mathrm{~min}$, annealing at $58^{\circ} \mathrm{C}$ for $1 \mathrm{~min}$, extension at $72^{\circ} \mathrm{C}$ for $1 \mathrm{~min}$ ( 35 cycles), final extension at $72^{\circ} \mathrm{C}$ for $5 \mathrm{~min}$.

In the first reaction the final volume of the mixture was $25 \mu \mathrm{l}$, consisting of $15.55 \mu \mathrm{l}$ of ultrapure water, $0.2 \mu \mathrm{l}$ of Taq polymerase $(5 \mathrm{U} / \mu \mathrm{L}), 0.5 \mu \mathrm{L}$ of each primer $(10 \mathrm{pmol}), 2 \mu \mathrm{L}$ of DNTP $(2.5 \mathrm{mM})$, $0.75 \mu \mathrm{L}$ of $\mathrm{Mg}(50 \mathrm{mM}), 2.5 \mu \mathrm{L}$ of buffer $(10 \mathrm{X})$ and $3 \mu \mathrm{L}$ of DNA. In the second reaction, the quantities were similar except for the volume of ultrapure water, which was $16.55 \mu \mathrm{L}$ and the added volume of one microliter of PCR product from the first reaction.

The snPCR $m s p 5$ positive samples were selected for evaluation of the $m s p 1 \alpha$ gene for strain differentiation in the positive animals. These samples were selected on random collection days so that all animals were evaluated at least one day. Thus, snPCR was performed with the primers 1733F (5'-TGTGCTTATGGCAGACATTTCC-3'), 3134R (5'-TCACGGTCAAAACCTTTGCTTACC-3') and 2957R (5-'AAACCTTGTAGCCCCAACTTATCC-3') for the target gene $m s p 1 \alpha$ (Lew et al. 2002). The reaction was performed under the following conditions: initial denaturation at $94^{\circ} \mathrm{C}$ for $4 \mathrm{~min}, 35$ cycles at $94^{\circ} \mathrm{C}$ for 30 seconds, $55^{\circ} \mathrm{C}\left(60^{\circ} \mathrm{C}\right.$ second reaction $)$ at $1 \mathrm{~min}$ and $72^{\circ} \mathrm{C}$ at $2 \mathrm{~min}$ followed by an extension final at $72^{\circ} \mathrm{C}$ for $7 \mathrm{~min}$. The first and second reactions were made with the final volume of the $25 \mu \mathrm{l}$ mix with the reagents at the same concentrations described in the SnPCR above. SnPCR products were analyzed on $1.5 \%$ agarose gel stained with ethidium bromide. Running time was $90 \mathrm{~min}, 80 \mathrm{~V}$ and intensity 160 .

Sequencing of the msp1 $\alpha$ gene in Anaplasma marginale. Molecular identification of the AmRio 2 strain was performed by sequencing fragments of the A. marginale $m s p 1 \alpha$ gene obtained from snPCR. The fragments were purified with ExoSAP-IT ${ }^{\circledR}$ PCR (USB ${ }^{\circledR}$ ) and sequenced by the Sanger method in DNA ABI 3730 Sequencer (Applied Biosystems, Life Technologies ${ }^{\circledR}$ ). The generated sequences were compared to data published using NCBI Nucleotide BLAST.

Statistical analysis. Initially data were described by means and means of standard error and were tested for distribution normality using the Kolmogorov-Smirnov test. Variables that did not meet the normality assumptions were submitted to logarithmic transformation $(\log 10)$ or square root $[R Q(X+1 / 2)]$. Then, the data were submitted to analysis of variance (ANOVA). When the ANOVA F test was significant, the contrast was averaged by the least significant difference (d.m.s.) of the Student-Newmn-Keuls test at
$5 \%$ probability $(\mathrm{p}=0.05)$. For the variables analysis, we used the procedure "General Linear Model" (GLM) of the statistical program "Statistical Analysis System" (SAS 2009).

\section{RESULTS}

\section{Clinical, hematological and parasitological aspects}

Two splenectomized cattle (Cattle 3 and 4) presented anaplasmosis at different times. Cattle 3 presented clinical alterations on the 9th day after infection (PID), which were characterized by apathy, decreased appetite, slight mucosal pallor, pasty feces, mean RT $39.8^{\circ} \mathrm{C}$, hematocrit $15 \%$ and $1 \%$ red blood cells infected with Anaplasma marginale corpuscles in the blood smear (Fig.1A). This animal spontaneously recovered in two days, confirmed by the absence of clinical signs and return of hematocrit to $25 \%$. However, the patient had recurrence in the 60th PID and had no appetite, poor body score (Fig.1B), sialorrhea, whitish ocular mucosa (Fig.1C), mild jaundice, evident tachycardia, ruminal and intestinal atony, TR of $40^{\circ} \mathrm{C}$, faecal stools (Fig.1D), some with mucus and blood streaks, $8 \%$ hematocrit and countless $A$. marginale inclusion corpuscles within red blood cells. This animal was treated with long-acting oxytetracycline, $20 \mathrm{mg} / \mathrm{kg}, 30 \%$ (5ml) intravenously and $70 \%$ (13ml) intramuscularly, three times, 24 hours apart; imidocarb dipropionate, $5 \mathrm{mg} / \mathrm{kg}$ subcutaneously, single application; blood transfusion (about $700 \mathrm{ml}$ of donor heifer blood) and fluiod otherapy (1l of $0.9 \%$ saline plus $500 \mathrm{ml}$ of vitamin complex). Eleven days later, the hematocrit returned to $25 \%$ and the animal had no clinical symptoms. However, after 19 days of treatment, the animal again presented symptoms more intensely described above and died. Cattle 4 presented $20 \%$ of hematocrit and countless inclusion corpuscles of $A$. marginale in the 42nd PID. Two days after hematocrit spontaneously returned to $26 \%$. However, at D46 the animal had mild apathy, faecal stools and mean RT of $39.7^{\circ} \mathrm{C}$, and died the next day.

An individual animal overview of the clinical and parasitological aspects is presented in Table 1. Regarding the means of RT when compared to values before inoculation, except for non-splenectomized buffaloes, the groups presented high RT during the whole evaluation period after inoculation of $A$. marginale strain AmRio 2, but with values within the normal reference range for the species. Only splenectomized cattle showed febrile peaks during the experiment (Fig.2). The hematocrit average of splenectomized cattle was below the values before inoculation and reference for the species in D9 and D60. Splenectomized buffaloes had a mean hematocrit below the values before inoculation and near the lower limit of the reference value for the species in D2 and D7. (Fig.3).

Cattle and buffalo blood count values are described in Tables 2 and 3, respectively. Both groups of buffaloes did not present alterations that differed statistically. However, we observed leukocyte elevation in these animals due to lymphocyte increase, when comparing the values before and after inoculation of the AmRio 2 strain of $A$. marginale. Despite the increase in white cells, the values remained within the reference range for the species (Abd Ellah et al. 2014).

As for cattle, the non-splenectomized group presented an increase in MCV with a statistical difference $(p<0.05)$, and the splenectomized group presented a decrease in red blood cells, hemoglobin, platelets and an increase in MCV 

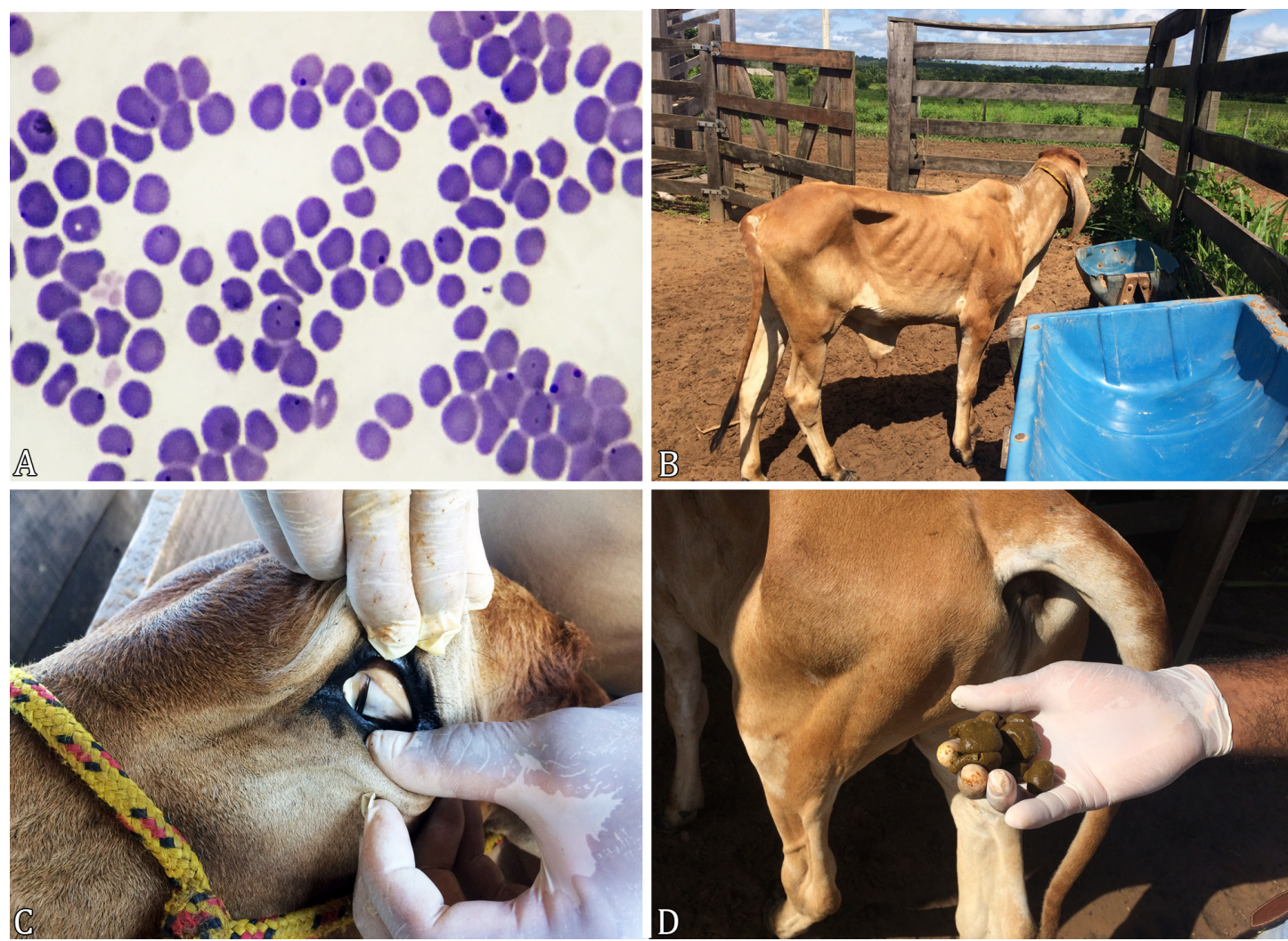

Fig.1. Experimental infection with AmRio 2 strain of Anaplasma marginale in cattle and buffalos. (A) Cattle 3 blood smear with presence of A. marginale corpuscles in PID 9. (B) Cattle 3 showing apathy and severe weight loss at 60th PID. (C) Cattle 3 with pale left ocular mucosa. (D) Cattle 3 with recently obtained rectal-shaped stools.

Table 1. Clinical symptomatology, post-infection day (PID) of clinical change, mean frequency of blood smear infection, mean rickshaemia, days of higher levels of rickettsemia, and recovery of buffalo and cattle experimentally infected with AmRio 2 strain of Anaplasma marginale

\begin{tabular}{|c|c|c|c|c|c|c|}
\hline Animal & $\begin{array}{c}\text { Clinical } \\
\text { symptomatology }\end{array}$ & PID & Blood smear (\%) & $\begin{array}{c}\text { Rickettsemia } \\
(\%)\end{array}$ & $\begin{array}{c}\text { Days of higher levels of } \\
\text { rickettsemia }\end{array}$ & Recovery \\
\hline $\begin{array}{l}\text { Cattle } 1 \\
\text { (non-splenectomized) }\end{array}$ & No & - & 47 & 0.73 & $\begin{array}{c}\text { D2 (4\%); D21 } \\
\text { (Uncountable) }\end{array}$ & - \\
\hline $\begin{array}{l}\text { Cattle } 2 \\
\text { (non-splenectomized) }\end{array}$ & No & - & 27 & 0.26 & D2 (1\%) & - \\
\hline $\begin{array}{l}\text { Cattle } 3 \\
\text { (splenectomized) }\end{array}$ & Yes & 9 th and 60 th & 38 & 0.62 & $\begin{array}{l}\text { D2 (6\%); D60 } \\
\text { (Uncountable) }\end{array}$ & $\begin{array}{c}\text { First, spontaneous. } \\
\text { Second, with treatment. } \\
\text { Then death. }\end{array}$ \\
\hline $\begin{array}{l}\text { Cattle } 4 \\
\text { (splenectomized) }\end{array}$ & Yes & 42nd e 46th & 23 & 0.38 & $\begin{array}{l}\text { D2 (4\%); D42 } \\
\text { (Uncountable) }\end{array}$ & $\begin{array}{c}\text { First, spontaneous. } \\
\text { Then death. }\end{array}$ \\
\hline $\begin{array}{l}\text { Buffalo } 1 \\
\text { (non-splenectomized) }\end{array}$ & No & - & 33 & 0.80 & D2 (Uncountable) & - \\
\hline $\begin{array}{l}\text { Buffalo } 2 \\
\text { (non-splenectomized) }\end{array}$ & No & - & 47 & 0.27 & D5 (2\%) & - \\
\hline $\begin{array}{l}\text { Buffalo } 3 \\
\text { (splenectomized) }\end{array}$ & No & - & 27 & 0.53 & D2 (6\%) & - \\
\hline $\begin{array}{l}\text { Buffalo } 4 \\
\text { (splenectomized) }\end{array}$ & No & - & 27 & 0.60 & $\begin{array}{c}\text { D2 (Uncountable); D5 } \\
(6 \%)\end{array}$ & - \\
\hline
\end{tabular}

after pellet inoculation with rickettsia. Red blood cell and platelet values in this latter group were above the reference range (Jain 1993) even before inoculation.

In both groups of cattle, we also observed an increase in leukocytes due to elevation of lymphocytes after inoculation, but without statistical difference. The values remained at the reference limit in non-splenectomized cattle, whereas in splenectomized cattle the average lymphocyte count after inoculation was slightly above the reference level (Jain 1993).

The pre-patent period (PPP), based on blood smear, was two days in all animals except Buffalo 2, which was of five days. The average incubation period (PI) in the sick cattle was 25.5 days and these animals died on average 63 days after inoculation of the Amrio 2 strain of $A$. marginale. 


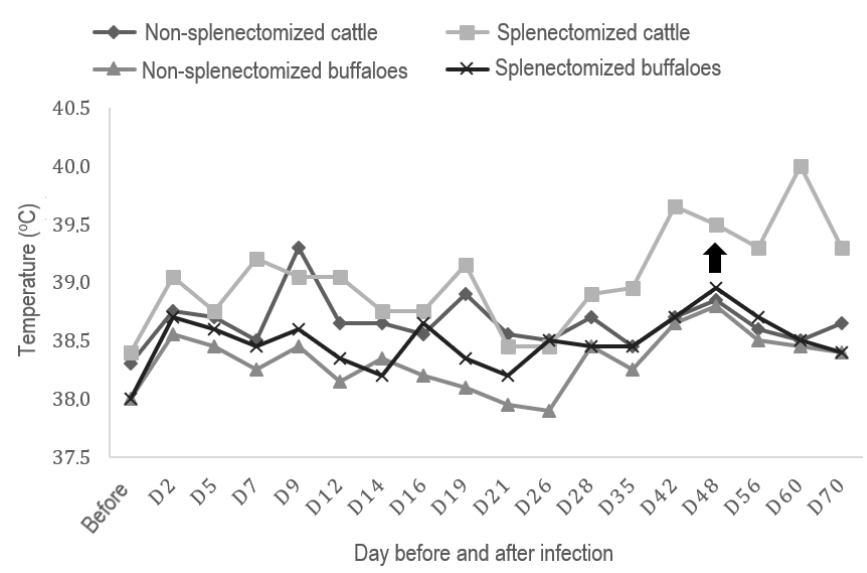

Fig.2. Mean rectal temperature (RT) values in buffalo and cattle before and after experimental infection with strain AmRio2 of Anaplasma marginale. From D48 ( $\uparrow$ ), in splenectomized cattle, the values correspond only to the results of Cattle 3 , due to the death of Cattle 4.

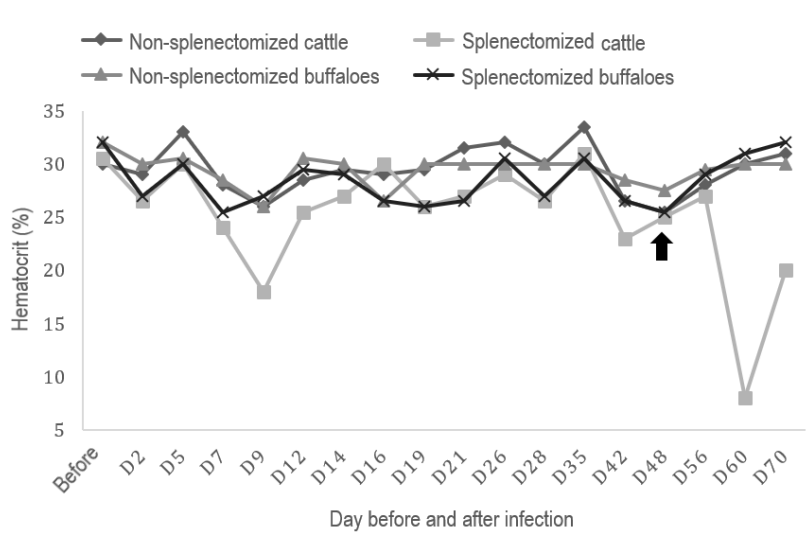

Fig.3. Mean hematocrit values in buffalo and cattle before and after experimental infection with strain AmRio2 of Anaplasma marginale. From D48 ( $\uparrow$ ), in splenectomized cattle, the values correspond only to the results of Cattle 3 , due to the death of Cattle 4.

Table 2. Mean values, mean standard error and significance of buffalo blood count before and after experimental infection with AmRio 2 strain of Anaplasma marginale

\begin{tabular}{|c|c|c|c|c|c|}
\hline \multirow{3}{*}{ Variables } & \multirow{3}{*}{ Unit } & \multicolumn{4}{|c|}{ Buffaloes } \\
\hline & & \multicolumn{2}{|c|}{ Non-splenectomized } & \multicolumn{2}{|c|}{ Splenectomized } \\
\hline & & Before & After & Before & After \\
\hline Red blood cells & $\mathrm{x} 10^{6} / \mu \mathrm{l}$ & $7.80 \pm 0.42$ & $8.13 \pm 0.23$ & $8.33 \pm 0.11$ & $8.11 \pm 0.17$ \\
\hline $\mathrm{ACV}^{*}$ & $\mathrm{fL}$ & $44.83 \pm 1.17$ & $44.84 \pm 0.86$ & $39.92 \pm 0.70$ & $41.13 \pm 0.26$ \\
\hline MCHC** & $\%$ & $33.77 \pm 0.21$ & $33.58 \pm 0.10$ & $34.13 \pm 0.28$ & $33.60 \pm 0.10$ \\
\hline Rods & $/ \mu \mathrm{l}$ & $61.75 \pm 17.76$ & $124.20 \pm 27.95$ & $123.63 \pm 11.15$ & $208.20 \pm 48.12$ \\
\hline Segmented & $/ \mu \mathrm{l}$ & $2641.25 \pm 287.55$ & $2949.80 \pm 687.18$ & $5334.50 \pm 899.14$ & $2393.60 \pm 911.04$ \\
\hline Lymphocytes & $/ \mu \mathrm{l}$ & $3824.50 \pm 860.61$ & $5791.30 \pm 674.36$ & $6841.38 \pm 767.10$ & $9247.60 \pm 947.10$ \\
\hline Eosinophils & $/ \mu \mathrm{l}$ & $72.38 \pm 26.38$ & $165.50 \pm 97.10$ & $43.63 \pm 28.42$ & $200.80 \pm 65.91$ \\
\hline Monocytes & $/ \mu \mathrm{l}$ & $165.63 \pm 31.59$ & $264.60 \pm 41.67$ & $389.50 \pm 111.10$ & $400.60 \pm 67.71$ \\
\hline
\end{tabular}

*ACV = Average corpuscular volume, ${ }^{* *} \mathrm{MCHC}=$ mean corpuscular hemoglobin concentration. Absence of different lowercase letters on the same line indicates that there was no significant difference ( $p>0.05$ ) within each group (non-splenectomized and splenectomized).

Table 3. Mean values, mean standard error and blood count significance of cattle before and after experimental infection by AmRio 2 strain of Anaplasma marginale

\begin{tabular}{|c|c|c|c|c|c|}
\hline \multirow{3}{*}{ Variables } & \multirow{3}{*}{ Unit } & \multicolumn{4}{|c|}{ Cattle } \\
\hline & & \multicolumn{2}{|c|}{ Non-splenectomized } & \multicolumn{2}{|c|}{ Splenectomized } \\
\hline & & Before & After & Before & After \\
\hline Red blood cells & $\mathrm{x} 10^{6} / \mu \mathrm{l}$ & $8.40 \pm 0.21$ & $7.85 \pm 0.21$ & $10.51 \pm 0.48^{\mathrm{a}}$ & $8.00 \pm 0.09^{b}$ \\
\hline $\mathrm{ACV}^{*}$ & $\mathrm{fL}$ & $38.85 \pm 0.58^{b}$ & $43.00 \pm 0.91^{\mathrm{a}}$ & $37.70 \pm 0.51^{\mathrm{b}}$ & $39.12 \pm 0.66^{\mathrm{a}}$ \\
\hline $\mathrm{MCHC}^{* *}$ & $\%$ & $34.03 \pm 0.43$ & $33.94 \pm 0.19$ & $34.43 \pm 0.77$ & $33.58 \pm 0.08$ \\
\hline Rods & $/ \mu \mathrm{l}$ & $59.13 \pm 19.84$ & $84.90 \pm 9.05$ & $74.38 \pm 24.93$ & $103.60 \pm 8.04$ \\
\hline Segmented & $/ \mu \mathrm{l}$ & $2630.00 \pm 406.67$ & $2427.50 \pm 477.27$ & $2208.05 \pm 274.17$ & $2307.80 \pm 376.02$ \\
\hline Lymphocytes & $/ \mu \mathrm{l}$ & $4394.63 \pm 447.31$ & $5364.40 \pm 402.22$ & $6546.63 \pm 944.89$ & $7551.70 \pm 429.80$ \\
\hline Eosinophils & $/ \mu \mathrm{l}$ & $107.75 \pm 22.95$ & $324.20 \pm 192.76$ & $96.00 \pm 48.10$ & $70.30 \pm 11.21$ \\
\hline Monocytes & $/ \mu \mathrm{l}$ & $251.38 \pm 25.84$ & $260.50 \pm 16.85$ & $327.13 \pm 43.65$ & $323.60 \pm 34.87$ \\
\hline
\end{tabular}

*ACV = Average corpuscular volume, ${ }^{* *} \mathrm{MCHC}=$ mean corpuscular hemoglobin concentration. Lowercase letters on the same line indicates that there was no significant difference ( $\mathrm{p}>0.05$ ) within each group (non-splenectomized and splenectomized) 


\section{Necropsy and histopathology findings}

Necropsy of both cattle revealed pale carcass, ascites, increased liver with rounded edges, full and distended gallbladder with thick bile, moderate jaundice and accumulation of dry stools in the rectum.

Histopathological analysis revealed moderate number of lymphocyte and mild macrophages infiltration into the heart, liver and kidney (Fig.4). Lymph nodes revealed histiocytic infiltration on the center of follicles. We also observed marked and diffuse hepatic sinusoid dilation, as well as diffuse cholestasis.

\section{SnPCR for target genes msp5 and msp1 $\alpha$}

All animals on D0 were negative for A. marginale AmRio2 target gene $m s p 5$, except non-splenectomized cattle, which remained positive even with treatment before starting the

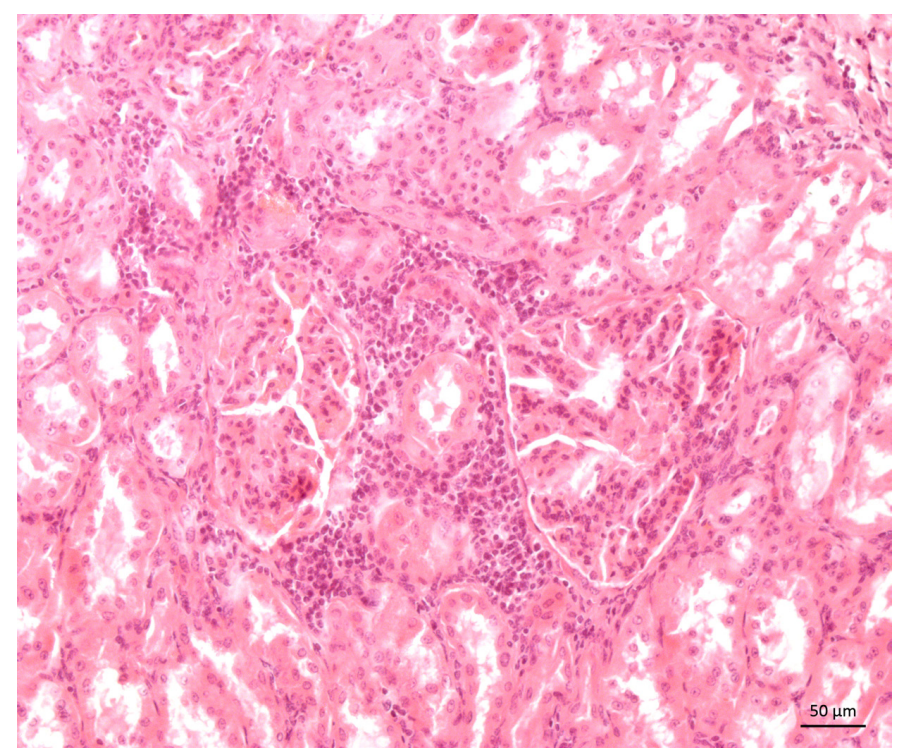

Fig.4. Experimental infection with strain AmRio 2 of Anaplasma marginale in buffaloes and cattle. Cattle 4 kidney with periglomerular lymphocytic infiltrate. HE, bar $=50 \mu \mathrm{m}$. study (Table 4). Positive animals were found to be more frequent from the time animals were raised on pasture (D35). Splenectomized cattle presented a higher average frequency of infection (50\%) than spleen-free buffaloes (25\%), and Buffalo 4 presented its first positive snPCR only two months after inoculation.

With the exception of Cattle 1 and 2 (non-splenectomized) and Buffalo 4 (splenectomized), during the period they remained in the stalls, there was considerable variation in the dynamics of infection, where animals detected as positive in one day did not necessarily continue the status in the following days.

The evaluation of the target gene msp $1 \alpha$ revealed a similar result to that found in D0 in the analysis of the msp5 gene. This confirmed that the animals were really negative at the beginning of the experiment, with execution of unsplenectomized cattle. On the following days, all samples selected for $m s p 1 \alpha$ screening were positive at least one time.

\section{Sequencing of msp1 $\alpha$ gene in Anaplasma marginale}

From the samples selected for sequencing, it was found that five animals (Cattle 2, 3 and 4; Buffalo 2 and 3) presented amino acid sequences $(\alpha \beta \beta \beta$ F) compatible with AmRio 2 strain of $A$. marginale.

\section{DISCUSSION}

In the present study, none of the buffaloes presented clinical signs of anaplasmosis, which differs from the findings of Sharma (1987) and Reddy et al. (1988) in experimental studies and those reported by Srivastava \& Ahluwalia (1974) and Vatsya et al. (2013) in natural cases. These studies were developed in India and no report was found on experimental infection of Anaplasma marginale in buffalo in Brazil. Therefore, our research is the first to simultaneously compare several aspects of anaplasmosis in cattle and buffalo experimentally infected with A. marginale strain AmRio 2 in this country.

Only splenectomized cattle showed clinical signs of the disease, which corroborate those described by Lopes et al. (2016), Silvestre et al. (2016) and Aktas \& Özübek (2017).

Table 4. Dynamics and frequency of infection with strain AmRio2 of Anaplasma marginale through Semi-Nested PCR for msp5 gene in experimentally infected buffaloes and cattle as a function of animal blood collection in stalls (D0 - D28) and in pasture (from D28)

\begin{tabular}{|c|c|c|c|c|c|c|c|c|c|c|c|c|c|c|c|c|c|c|c|}
\hline & D0 & D2 & D5 & D7 & D9 & D12 & D14 & D16 & D19 & D21 & D26 & D28 & D35 & $\mathrm{D} 42$ & $\mathrm{D} 48$ & D56 & D60 & D70 & Frequency \\
\hline $\begin{array}{l}\text { Cattle } 1 \\
\text { (intact) }\end{array}$ & + & + & + & + & + & + & + & + & + & + & + & + & + & + & + & - & + & + & $94 \%(17 / 18)$ \\
\hline $\begin{array}{l}\text { Cattle } 2 \\
\text { (intact) }\end{array}$ & + & + & + & + & + & + & + & + & + & + & + & + & + & + & + & + & + & + & $100 \%(18 / 18)$ \\
\hline $\begin{array}{l}\text { Cattle } 3 \\
\text { (splenectomized) }\end{array}$ & - & + & - & - & - & - & - & - & - & - & + & + & + & + & + & + & + & + & $50 \%(9 / 18)$ \\
\hline $\begin{array}{l}\text { Cattle } 4 \\
\text { (splenectomized) }\end{array}$ & - & + & - & - & - & - & - & + & - & + & + & + & + & + & \multicolumn{4}{|c|}{ Death } & $50 \%(7 / 14)$ \\
\hline $\begin{array}{l}\text { Buffalo } 1 \\
\text { (intact) }\end{array}$ & - & - & - & - & - & - & - & + & - & + & - & - & + & + & - & + & + & + & $39 \%(7 / 18)$ \\
\hline $\begin{array}{l}\text { Buffalo } 2 \\
\text { (intact) }\end{array}$ & - & - & - & - & - & - & - & + & - & - & - & - & - & + & + & - & + & - & $22 \%(4 / 18)$ \\
\hline $\begin{array}{l}\text { Buffalo } 3 \\
\text { (splenectomized) }\end{array}$ & - & - & - & - & - & + & - & + & - & - & - & + & - & + & + & + & + & - & $39 \%(7 / 18)$ \\
\hline $\begin{array}{l}\text { Buffalo } 4 \\
\text { (splenectomized) }\end{array}$ & - & - & - & - & - & - & - & - & - & - & - & - & - & - & - & - & + & + & $11 \%(2 / 18)$ \\
\hline
\end{tabular}

+ Positive animal, - negative animal. 
On the other hand, other experimental studies have reported mild clinical signs of anaplasmosis in splenectomized calves (Doyle et al. 2016a, Silvestre et al. 2016).

The frequency of positive animals for blood smear evaluation was similar between buffaloes (33.5\%) and cattle $(33.7 \%)$, as well as the mean values of rickettsemia in both buffaloes $(0.55 \%)$ and cattle $(0.50 \%)$. In general, the peak of rickettsemia in both species occurred in the 2nd PID. These findings differ from those verified by Reddy et al. (1988), who reported $8.5 \%$ of rickettsemia at the 29th PID in buffalo calves, and those reported by Gale et al. (1996), who found $2 \%$ to $34 \%$ of parasitized red blood cells with peaks between 12th to 24th PID in Hereford calves.

In the present study, two days of PPP and 25.5 days of PI were observed. Santos (2016) reported four-day PPP for A. marginale strain AmRio 1. According to Kocan et al. (2010), the PI can range from 7 to 60 days. The evolution of the clinical condition until the death of splenectomized cattle lasted on average 63 days and this shows that the strain presented high pathogenicity for this group.

Regarding temperature, only splenectomized cattle presented hyperthermia. This finding is in agreement with that verified by Silvestre et al. (2016), who observed fever of up to $40.2^{\circ} \mathrm{C}$ in experimentally infected cattle.

Marked changes were observed in splenectomized cattle for the manual hematocrit evaluation, which presented values below 15\%, similar to that verified by Gale et al. (1996) and Lopes et al. (2016). On the other hand, non-splenectomized cattle and buffaloes, as well as splenectomized buffaloes, did not present significant changes in hematocrit, contrary to what was reported by Reddy et al. (1988) in buffaloes with spleen $(20.6 \%)$.

Regarding the variables analysis on the erythrogram, both buffalo groups did not show any significant differences before and after inoculation. These data differ from those found in a case of natural infection by Vatsya et al. (2013). In relation to cattle, the alterations observed were greater in splenectomized animals, which were characterized by reduction of red blood cells, hemoglobin and platelets. The non-splenectomized cattle presented only increase of MCV. Doyle et al. (2016a) also reported a reduction in red blood cell count and hemoglobin concentration in splenectomized cattle.

Based on the white blood cell count, although not statistically significant, both non-splenectomized and splenectomized buffaloes and cattle showed elevation of leukocytes due to an increase in lymphocyte count, a change also reported by other authors (Doyle et al. 2016a, Silvestre et al. 2016). The decrease in red blood series elements is related to the decreased lifetime of red blood cells in the circulation caused by extravascular erythrophagocytosis due to the presence of rickettsia in the circulation (Massard et al. 1998). In relation to lymphocyte elevation, it probably represents an antigenic stimulation in response to A. marginale (Brown 2012).

Splenectomized animals had a high platelet count when compared to non-splenectomized animals of both species. However, when comparing the moments before and after inoculation, there was a decrease in the number of platelets in all groups evaluated. These results resemble those of Doyle et al. (2016b), who observed a significant decrease in platelets in splenectomized and intact cattle in the days after infection. Normally, up to one third of platelets are sequestered by the spleen (Randolph et al. 2010) and with surgical removal of this organ storage is impaired, which probably influenced the platelet values found in the present study. Transient or persistent thrombocytosis may also occur in asplenic humans (Sumaraju et al. 2001, Resende \& Petroianu 2002).

The death of splenectomized cattle may be related to the greater susceptibility of these animals due to the absence of the spleen, as splenectomy impairs the formation of $\mathrm{M}$ immunoglobulins that appear at the beginning of the immune response (Klaus \& Jones 1968). In contrast to cattle, buffaloes showed no clinical alteration. Therefore, it is suggested that buffaloes were more resistant when compared to cattle with respect to the strain evaluated in this study. In a similar study with Babesia bovis, Benitez et al. (2018) also observed that buffaloes did not show clinical symptoms and suggested that these animals had the ability to eliminate or significantly reduce circulatory hemorrhomas by an innate immunity mechanism.

Necropsy findings of splenectomized cattle were similar to those found in animals with anaplasmosis. According to Coetzee et al. (2005), these findings include severe anemia, jaundice, hepatosplenomegaly, petechial haemorrhages in the heart and pericardium, flabbiness and pallor of the heart. Histopathology revealed inflammatory process characterized by mononuclear cell infiltration into various organs. In addition, there was dilation of the liver sinusoids and cholestasis. These findings were similar to those described by Santos (1967).

Over 10 weeks of snPCR evaluation for the msp 5 target gene, there was a very variable infection dynamics, in which positive animals on one day did not necessarily continue their status on the following days. Animals that survive acute infection of $A$. marginale develop persistent infections characterized by low-level cyclic rickettsemia (Kieser et al. 1990, French et al. 1999).

Still on the snPCR for the msp5 target gene, the non-splenectomized cattle started the positive experiment even after treatment against $A$. marginale. Based on sequencing, we found that these animals were infected with a native strain of this rickettsia. It is believed that the drugs used were not able to sufficiently reduce the amount of bacterial DNA in the bloodstream of animals to levels undetectable by snPCR. The rest of the animals responded to the treatment and started the snPCR negative search. When evaluating Table 4, the highest frequency of infection was at the time animals were on pasture. Two hypotheses may support this. The first, the animals came into contact with native strains of A. marginale from the moment they went to pasture, which contributed to a greater detection in snPCR for $m s p 5$ gene, present in several Anaplasma species and used for serological and molecular screening studies (Torioni de Echaide et al. 1998, Bacanelli et al. 2014). The second, over time, the AmRio 2 strain increased the number of DNA copies in the circulatory current of the ruminants and, consequently, contributed to a higher sensitivity of the molecular examination and this can be supported by the fact that this time (pasture period) includes the period when rickettsemia increases ( 2 to 6 weeks after infection), in which levels of $10^{9}$ or more bacteria per milliliter of blood can be verified by quantitative PCR (Futse et al. 2003, Han et al. 2010). The last hypothesis is the most likely.

In the comparative analysis of the snPCR result for $m s p 5$ gene among splenectomized animals, cattle presented a significantly higher average frequency of infection than 
buffaloes. Other studies also reported that buffaloes had lower values (Silva et al. 2014a, 2014b) compared to the observed in cattle (Bacanelli et al. 2014). A splenectomized buffalo was positive only 60 days after inoculation. It is likely that this animal had low rickettsemia in the period prior to the 60th PID, which possibly influenced the detection sensitivity of A. marginale DNA copies by $m s p 5$ snPCR.

From the positive samples in the msp5 gene evaluation, random animal samples were selected to be tested by $m s p 1 \alpha$ target gene snPCR and $100 \%$ of the positive samples were found on at least one evaluation day. This indicates that the AmRio strain 2 actually caused infection in the animals, except in non-splenectomized cattle (Cattle 1 and 2), since they started the experiment positive for $A$. marginale. The fact that they were snPCR-positive for the $m s p 1 \alpha$ gene may be related to the native strain in which these animals housed.

Despite the positive results observed in snPCR, analysis of the amino acid sequences based on the $m s p 1 \alpha$ gene revealed that only five ruminants (Cattle 2, 3 and 4; Buffalo 2 and 3) showed similarity with $A$. marginale strain AmRio 2 tandem repeat sequence $(\alpha \beta \beta \beta F)$, as described first by Baêta et al. (2015). In these individuals it was possible to prove the infection by the strain under study. In the remaining animals (Cattle 1; Buffalo 1 and 4), the non-presentation of A. marginale AmRio2-like strain should be further investigated in future studies.

\section{CONCLUSIONS}

Blood smear and snPCR showed that AmRio 2 strain of Anaplasma marginale caused infection in experimentally infected buffalo and cattle. Based on the association of clinical, parasitological, histopathological and molecular findings, it was concluded that two splenectomized cattle died due to anaplasmosis caused by this strain.

Under the conditions of this experiment, buffaloes were more resistant to anaplasmosis than cattle, as they showed no relevant clinical and laboratory alterations after rickettsia inoculation.

According to our research data, buffaloes may be an alternative to raising cattle in areas with high frequency of clinical cases of anaplasmosis.

Acknowledgments. This study was financed in part by the "Coordenação de Aperfeiçoamento de Pessoal de Nível Superior” (CAPES), Brazil, Finance Code 001 , through a doctorate scholarship, for which we are grateful. We also thank the "Instituto Federal do Pará", “Campus Rural de Marabá” (IFPA-CRMB) and the "Universidade Federal Rural do Rio de Janeiro" (UFRRJ) for the provision of personnel and infrastructure to carry out the research; to the Oswaldo Cruz Foundation (Fiocruz) for the sequencing, and to VALE S/A for the provision of hydrometeorological data.

\section{REFERENCES}

Aubry P. \& Geale D.W. 2011. A review of bovine anaplasmosis. Transbound. Emerg. Dis. 58(1):1-30. <http://dx.doi.org/10.1111/j.1865-1682.2010.01173.x> $<$ PMid:21040509>

Abd Ellah M.R., Hamed M.I., Ibrahim D.R. \& Rateb H.Z. 2014. Serum biochemical and haematological reference intervals for water buffalo (Bubalus bubalis) heifers. J. S. Afr. Vet. Assoc. 85(1):1-7. <PMid:24831856>

Aktas M. \& Özübek S. 2017. Outbreak of anaplasmosis associated with novel genetic variants of Anaplasma marginale in a dairy cattle. Comp. Immunol. Microbiol. Infect. Dis. 54:20-26. <http://dx.doi.org/10.1016/j. cimid.2017.07.008><PMid:28915997>
Bacanelli G.M., Ramos C.A.N. \& Araújo F.R. 2014. Molecular diagnosis of Anaplasma marginale in cattle: quantitative evaluation of a real-time PCR (Polymerase Chain Reaction) based on $m s p 5$ gene. Pesq. Vet. Bras. 34(1):29-33. <http://dx.doi.org/10.1590/S0100-736X2014000100005>

Baêta B.A., Ribeiro C.C., Teixeira R.C., Cabezas-Cruz A., Passos L.M.F., Zweygarth E. \& Fonseca A.H. 2015. Characterization of two strains of Anaplasma marginale isolated from cattle in Rio de Janeiro, Brazil, after propagation in tick cell culture. Ticks Tick Borne Dis. 6(2):141-145. <http://dx.doi. org/10.1016/j.ttbdis.2014.11.003 ><PMid:25468764>

Benitez D., Mesplet M., Echaide I., Torioni de Echaide S., Schnittger L. \& Florin-Christensen M. 2018. Mitigated clinical disease in water buffaloes experimentally infected with Babesia bovis. Ticks Tick Borne Dis. 9(5):13581363. <http://dx.doi.org/10.1016/j.ttbdis.2018.04.012><PMid:29724619>

Brown W.C. 2012. Adaptive immunity to Anaplasma pathogens and immune dysregulation: implications for bacterial persistence. Comp. Immunol. Microbiol. Infect. Dis. 35(3):241-252. http://dx.doi.org/10.1016/j. cimid.2011.12.002><PMid:22226382.

Coetzee J.F., Apley M.D., Kocan K.M., Rurangirwa F.R. \& Van Donkersgoed J. 2005. Comparison of three oxytetracycline regimens for the treatment of persistent Anaplasma marginale infections in beef cattle. Vet. Parasitol. 127(1):61-73. <http://dx.doi.org/10.1016/j.vetpar.2004.08.017> $<$ PMid:15675047>

Dirksen G., Gründer H.D. \& Stöber M. 1993. Rosemberger: exame clínico dos bovinos. $3^{\underline{a}}$ ed. Guanabara Koogan, Rio de Janeiro, 419p.

Doyle R.L., França R.T., Oliveira C.B., Rezer J.F.P., Klafke G.M., Martins J.R., Santos A.P., Nascimento N.C., Mesick J.B., Lopes S.T.A., Leal D.B.R., Silva A.S. \& Andrade C.M. 2016a. Cattle experimentally infected by Anaplasma marginale: Influence of splenectomy on disease pathogenesis, oxidative profile, and antioxidant status. Microb. Pathog. 95:193-199. <http://dx.doi. org/10.1016/j.micpath.2016.04.011 ><PMid:27060744>

Doyle R.L., Oliveira C.B., França R.T., Doleski P.H., Souza V.C., Leal D.B.R., Martins J.R., Lopes S.T.A., Machado G., Silva A.S. \& Andrade C.M. 2016b. Influence of experimental Anaplasma marginale infection and splenectomy on NTPDase and 5'nucleotidase activities in platelets of cattle. Microb. Pathog. 95:49-53. <http://dx.doi.org/10.1016/j.micpath.2016.02.019> <PMid:26945560>

French D.M., Brown W.C. \& Palmer G.H. 1999. Emergence of Anaplasma marginale antigenic variants during persistent rickettsia. Infect. Immun. 67(11):5834-5840. <PMid:10531237>

Futse J.E., Ueti M.W., Knowles Junior D.P. \& Palmer G.H. 2003. Transmission of Anaplasma marginale by Boophilus microplus: retention of vector competence in the absence of vector-pathogen interaction. J. Clin. Microbiol. 41(8):3829-3834. <http://dx.doi.org/10.1128/JCM.41.8.3829-3834.2003> <PMid:12904396>

Gale K.R., Leatch G., DeVos A.J. \& Jorgensen W.K. 1996. Anaplasma marginale: effect of challenge of cattle with varying doses of infected erythrocytes. Int. J. Parasit. 26(12):1417-1420. <http://dx.doi.org/10.1016/S00207519(96)00133-6><PMid:9024896>

Grau H.E., Cunha Filho N.A., Pappen F.G. \& Farias N.A. 2013. Transplacental transmission of Anaplasma marginale in beef cattle chronically infected in southern Brazil. Revta Bras. Parasitol. Vet. 22(2):189-193. <http://dx.doi. org/10.1590/S1984-29612013000200038> <PMid:23856734>

Han S., Norimine J., Brayton K.A., Palmer G.H., Scoles G.A. \& Brown W.C. 2010. Anaplasma marginale infection with persistent high-load bacteremia induces a dysfunctional memory CD4+ T lymphocyte response but sustained high IgG titers. Clin. Vaccine Immunol. 17(12):1881-1890. <http://dx.doi. org/10.1128/CVI.00257-10><PMid:20943884>

IBGE 2016. Produção da Pecuária Municipal (PPM).Vol.44. Instituto Brasileiro de Geografia e Estatística, Rio de Janeiro, 51p.

Jain N.C. 1993. Essentials of Veterinary Hematology. Lea and Febiger, Philadelphia. 1344p. 
Kieser S.T., Eriks I.E. \& Palmer G.H. 1990. Cyclic rickettsia during persistent Anaplasma marginale infection in cattle. Infect. Immun. 58(4):1117-1119. <PMid:2318532>

Klaus G.G.B. \& Jones E.W. 1968. The immunoglobulin response in intact and splenectomized calves infected with Anaplasma marginale. J. Immunol. 100(5):991-999. <PMid:4171949>

Kocan K.M., De la Fuente J., Guglielmone A.A. \& Melendez R.D. 2003. Antigens and alternatives for control of Anaplasma marginale infection in cattle. Clin. Microbiol. Rev. 16(4):698-712.<http://dx.doi.org/10.1128/CMR.16.4.698712.2003><PMid:14557295>

Kocan K.M., De la Fuente J., Blouin E.F., Coetzee J.F. \& Ewing S.A. 2010. The natural history of Anaplasma marginale. Vet. Parasitol. 167(2/4):95-107. <http://dx.doi.org/10.1016/j.vetpar.2009.09.012> <PMid:19811876>

Kocan K.M., De la Fuente J. \& Cabezas-Cruz A. 2015. The genus Anaplasma: new challenges after reclassification. Rev. Sci. Tech. Off. Int. Epiz. 34(2):577-586. <http://dx.doi.org/10.20506/rst.34.2.2381><PMid:26601458>

Lew A.E., Bock R.E., Minchin C.M. \& Masaka S. 2002. A $m s p 1 \alpha$ polymerase chain reaction assay for specific detection and differentiation of Anaplasma marginale isolates. Vet. Microbiol. 86(4):325-335. <http://dx.doi.org/10.1016/ S0378-1135(02)00017-2><PMid:11955782>

Lopes W.D.Z., Martins J.R.S., Costa A.J., Soares V.E., Texeira W.F., Cruz B.C., Maciel W., Felippelli G. \& Carvalho R.S. 2016. Aspectos da infecção por Anaplasma marginale em bovinos experimentalmente infectados. Vet. Zootec. 23(2):272-284.

Massard C.L., Soares C.O., Fonseca A.H. \& Madruga C.L. 1998. Tristeza Parasitária Bovina: histórico, biologia e modalidades de transmissão de Babesia bovis, B. bigemina e Anaplasma marginale aos bovinos. Embrapa-CNPGC, Campo Grande, MS, p.77-90. (Curso sobre controle do carrapato em bovinos, Compilação dos trabalhos apresentados)

Moraes Júnior R.J., Garcia A.R., Santos N.F.A., Nahúm B.S., Lourenço Junior J.B., Araújo C.V. \& Costa N.A. 2010. Conforto ambiental de bezerros bubalinos (Bubalus bubalis Linnaeus, 1758) em sistemas silvipastoris na Amazônia Oriental. Acta Amaz. 40(4):629-640. <http://dx.doi.org/10.1590/S0044$59672010000400001>$

Randolph J.F., Peterson M.E. \& Stokol T. 2010. Erythrocytosis and polycythemia, p.162-163. In:Weiss D.J. \& Wardrop K.J. (Eds), Schalm's Veterinary Hematology. 6 a ed. Wiley-Blackwell, Iowa.

Resende V. \& Petroianu A. 2002. Funções do remanescente esplênico após esplenectomia subtotal para o tratamento de lesões complexas do baço humano. Revta Assoc. Med. Bras. 48(1):26-31. <http://dx.doi.org/10.1590/ S0104-42302002000100028>

Reddy G.R., More T., Sharma S.P. \& Singh L.N. 1988. The oxidant defense system in water-buffaloes (Bubalus bubalis) experimentally infected with Anaplasma marginale. Vet. Parasitol. 27(3/4):245-249. <http://dx.doi. org/10.1016/0304-4017(88)90039-8><PMid:3369075>

Sambrook J. \& Russel D.W. 2001. Rapid isolation of mammalian DNA, p.6.286.29. In: Sambrook J. (Eds), Molecular Cloning: a laboratory manual. 3rd ed. Cold Spring Harbor Laboratory Press, New York.

Santos J.A. 1967. Contribuição ao estudo da anatomia patológica da anaplasmose bovina. Pesq. Agropec. Bras. 2:391-410.
Santos P.N. 2016. Caracterização molecular e análise filogenética da cepa AmRio1 de Anaplasma marginale em bezerro e carrapatos experimentalmente infectados. Master's Thesis, Universidade Federal Rural do Rio de Janeiro, Seropédica, RJ. 39p.

Sharma S.P. 1987. Characterization of Anaplasma marginale infection in buffaloes. Indian J. Anim. Sci. 57:76-78.

Singh H., Jyoti, Haque M., Singh N.K. \& Rath S.S. 2012. Molecular detection of Anaplasma marginale infection in carrier cattle. Tick Tick Borne Dis. 3(1):5558. <http://dx.doi.org/10.1016/j.ttbdis.2011.10.002><PMid:22309860>

Silva J., Vinhote W.M., Oliveira C.M., André M.R., Machado R.Z., Fonseca A.H. \& Barbosa J.D. 2014a. Molecular and serological prevalence of Anaplasma marginale in water buffaloes in the northern Brazil. Tick Tick Borne Dis. 5(2):100-104. <http://dx.doi.org/10.1016/j.ttbdis.2013.09.007> $<$ PMid:24246707>

Silva J.B., Fonseca A.H., Barbosa J.D., Cabezas-Cruz A. \& De la Fuente J. 2014b. Low genetic diversity associated with low prevalence of Anaplasma marginale in water buffaloes in Marajó Island, Brazil. Tick Tick Borne Dis. 5(6):801804.<http://dx.doi.org/10.1016/j.ttbdis.2014.06.003><PMid:25108778>

Silva J.B., Lopes C.T.A., Souza M.G.S., Gibson A.F.B., Vinhote W.M.S., Fonseca A.H., Araújo F.R. \& Barbosa-Neto J.D. 2014c. Detecção sorológica e molecular de Anaplasma marginale em búfalos na Ilha de Marajó, Pará. Pesq. Vet. Bras. 34(1):11-14. <http://dx.doi.org/10.1590/S0100-736X2014000100002>

Silva J.B., Fonseca A.H. \& Barbosa J.D. 2015. Molecular characterization of Anaplasma marginale in ticks naturally feeding on buffaloes. Infect. Genet. Evol. 35:38-41. <http://dx.doi.org/10.1016/j.meegid.2015.07.027> <PMid:26209411>

Silvestre B.T., Silveira J.A.G., Meneses R.M., Facury-Filho E.J., Carvalho A.U. \& Ribeiro M.F.B. 2016. Identification of a vertically transmitted strain from Anaplasma marginale (UFMG3): molecular and phylogenetic characterization, and evaluation of virulence. Tick Tick Borne Dis. 7(1):80-84. <http://dx.doi. org/10.1016/j.ttbdis.2015.09.001><PMid:26381444>

Srivastava R. \& Ahluwalia S.S. 1974. A clinical case of anaplasmosis in buffalo Indian Vet. J. 51:371-374.

Sumaraju V., Smith L.G. \& Smith S.M. 2001. Infectious complications in asplenic hosts. Infect. Dis. Clin. N. Am. 15(2):551-565, x. <http://dx.doi.org/10.1016/ S0891-5520(05)70159-8><PMid:11447709>

SAS 2009. SAS $/$ STAT $^{\circledR} 9.2$ User’s Guide. SAS Institute Inc., Cary, NC.

Thrall M.A., Baker D.C., Campbell T.W., Denicola D., Lassen E.D., Rebar A. \& Weise R.G. 2007. Hematologia e Bioquímica Clínica Veterinária. 2aㅡ ed. Roca, São Paulo. 582p.

Torioni de Echaide S., Knowles D.P., McGuire T.C., Palmer G.H., Suarez C.E. \& McElwain T.F. 1998. Detection of cattle naturally infected with Anaplasma marginale in a region of endemicity by nested PCR and a competitive enzyme-linked immunosorbent assay using recombinant major surface protein 5. J. Clin. Microbiol. 36(3):777-782. <PMid:9508311>

Vatsya S., Kumar R.R., Singh V.S. \& Arunraj M.R. 2013. Anaplasma marginale infection in a buffalo: a case report. Vet. Res. Int. 1(2):51-53. 